\title{
BIOLOGICAL EFFICACY OF MIXED LIGAND COPPER(II) COMPLEXES OF N(4)-SUBSTITUTED THIOSEMICARBAZONE AND DIIMINE CO-LIGANDS AS CHELATING N, N’- DONOR LIGAND
}

\author{
NEELAVENI RAJENDRAN ${ }^{1}$, NITHYA KAMATCHI ${ }^{2}$, VASANTHA SOLOMON ${ }^{1 *}$ \\ ${ }^{1}$ Department of Chemistry, Lady Doak College, Madurai, Tamil Nadu, India. ${ }^{2}$ Department of Zoology, Lady Doak College, Madurai, \\ Tamil Nadu, India. Email: vasantha@ldc.edu.in
}

Received: 20 April 2019, Revised and Accepted: 30 May 2019

\section{ABSTRACT}

Objective: In modern years, the biggest dare is to develop new chemotherapeutic agents with high efficiency as well as low toxicity. Hence, to defeat this challenge, extensive endeavors were taken on thiosemicarbazone based metal complexes.

Methods: A sequence of nine thiosemicarbazone based diimine copper(II) complexes derived from three sulfur-containing ligands $N$-methyl-2((1-methyl-1H-pyrrol-2-yl)methylene)hydrazinecarbothioamide H(L1), $N$-ethyl-2-((1-methyl-1H-pyrrol-2-yl)methylene)hydrazinecarbothioamide H(L2), and N-benzyl-2-((1-methyl-1H-pyrrol-2-yl)methylene)hydrazinecarbothioamide H(L3). The molecular structures and coordination possibilities of thiosemicarbazone ligands toward the central metal ions have been validated by analytical and spectral techniques such as molar conductance, elemental analysis, ultraviolet-Vis, Fourier-transform infrared, and electron paramagnetic resonance spectroscopy confirms that the thiosemicarbazones ligands are coordinated to copper through NS' donor and NN' donor of diimine. The antimicrobial activity and DNA cleavage effectiveness of thiosemicarbazone derivatives and copper(II) complexes were assessed by disc diffusion and agarose gel electrophoresis methods.

Results: All the spectral studies authenticated that the square planar geometry of the thiosemicarbazone copper(II) complexes 1-9. From the results of antibacterial activity against selected Gram-positive (Bacillus thuringiensis) and Gram-negative (Escherichia coli) bacterial strains, complex 8 exhibited noteworthy activity. Interestingly, copper(II) complexes bearing 1,10-phenanthroline (phen) moiety displayed outstanding results together with N(4)-substituted thiosemicarbazone derivatives and causes complete DNA degradation of SC (supercoiled) pUC18 DNA.

Conclusion: A variety of substitutions at the thioamide nitrogen atoms have shown potential biological activity. Henceforth, $N(4)$-substituted thiosemicarbazone based copper(II) complexes virtually reach the effectiveness of conventional chemotherapeutic drugs.

Keywords: Thiosemicarbazide, SC pUC18 DNA, Ascorbic acid, 2,2'-bipyridyl, Heterocyclic bases.

(C) 2019 The Authors. Published by Innovare Academic Sciences Pvt Ltd. This is an open access article under the CC BY license (http://creativecommons. org/licenses/by/4. 0/) DOI: http://dx.doi.org/10.22159/ajpcr.2019.v12i7.33678

\section{INTRODUCTION}

Cancer is one of the world's top killer diseases and it has overtaken heart disease according to 2010 reports, which should be more than higher and causes lots of deaths by 2030. To defeat the drawback of limited usefulness, toxicity and side effects of the commercially available anticancer drug, accordingly good alternatives were made through the discovery of new drugs for cancer therapy $[1,2]$. However, the mixed N/S donors of thiosemicarbazone ligands derived from the combination of an aldehyde or ketone and these groups of ligands are useful for achieving coordination spheres of transition metal complexes. These ligands and their metal complexes have received the extensive notice due to their availability of variable bonding modes, an electron donor's property of ligand, the position of a ligand inside the coordination sphere, structural variety, ion sensing capability, potential biological applications, and the stability of ligands and complexes [3,4]. In the last few decades, a huge number of thiosemicarbazone chemotherapeutic anticancer drugs are reported and some of the compounds are various phases of clinical trials [5]. Significantly, the biological properties of thiosemicarbazone compounds are comparativelyhigher than that of the other transitionmetal complexes probably due to the synergic effect among thiosemicarbazone ligands and the presence of central metal ion [6]. Recently, Zhu et al. found that potential biological properties of novel $N(4)$-substituted thiosemicarbazide with pyrrole moiety against PC-9, Eca-109, and SGC7901 cell lines [7]. Moreover, the substituted thiosemicarbazone at $N(4)$ position did not show any effect on the geometry of the complexes, but it influences the biological activity of the corresponding complexes and shows significant activity. Mounting evidence from literature, the synthesis of 1-methyl-2-pyrrolecarboxaldehyde with thiosemicarbazide in the presence of ethanol has been reported by Yurttaş et al. [8], and it is planned to modify with substituted thiosemicarbazide derivatives using glacial acetic acid, ethanol, and water. Likewise, phenyl and ethyl substituted thiosemicarbazone ligands were prepared. However, this was the first report which proved the biological properties of the mixed ligand thiosemicarbazone copper(II) complexes. Consequently, the biological potential of those substituted ligands H(L1) - H(L3) and its mixed ligand copper(II) complexes 1-9 with diimine coligands (phen/bpy) have been studied and reported for their future prospects. It is hoped that this work will be afforded some potential biological properties of mixed ligand thiosemicarbazone copper(II) complexes.

\section{MATERIALS}

\section{Chemicals used}

All the commercially available chemicals such as 1-methyl-2pyrrolecarboxaldehyde, 4-methyl-3-thiosemicarbazide, 4-phenyl-3thiosemicarbazide, 4-ethyl-3-thiosemicarbazide, 1, 10-phenanthroline, and 2, 2'-bipyridyl were purchased from Sigma-Aldrich (USA). The chemicals, ethidium bromide (EB), Tris- $\mathrm{HCl}$, agarose (molecular biology grade), and boric acid used for the DNA cleavage studies were procured from Merck (USA). The solvents and reagents for the synthesis of ligands and copper(II) complexes were obtained from Sigma-Aldrich (USA), Merck (USA), and Reachem (India), respectively.

\section{METHODS}

\section{Instrumentation}

The molar conductance of the synthesized thiosemicarbazone ligands and copper(II) complexes was determined using Elico CM 183 EC-TDS analyzer 
in Dimethyl formamide (DMF) $\left(1 \times 10^{-3} \mathrm{M}\right)$ at room temperature. Elemental analyses (C, H, N, and S) of the compounds were attained by Vario EL-III elemental analyzer. In addition, the structures of the thiosemicarbazone ligands were confirmed by Bruker $300 \mathrm{MHz}$ spectrophotometer using $\mathrm{CDCl}_{3}$ as a solvent and TMS (Tetramethylsilane) as an internal standard. The Fourier-transform infrared (FT-IR) spectra were carried out on a SHIMADZU IR TRACER 100 spectrophotometer using $\mathrm{KBr}$ discs in the range $4000-400 \mathrm{~cm}^{-1}$. The ultraviolet (UV)-Vis spectra of the ligands and copper(II) complexes were recorded using JASCO V-630 UV-Vis spectrophotometer in the range $200-1000 \mathrm{~nm}$. The X-band electron paramagnetic resonance (EPR) of the copper(II) complexes was recorded using ESR JEOL JES-FA200 in frozen solutions of DMF. The room temperature measurement was made by VARIAN ESR-112 spectrometer.

\section{BIOLOGICAL EVALUATION}

\section{Antibacterial screening}

The minimum inhibitory concentration (MIC) of synthesized thiosemicarbazone ligands and copper(II) complexes (5 and $50 \mu \mathrm{g} / \mathrm{ml}$ ) was investigated by agar disc diffusion $[9,10]$ against Bacillus thuringiensis (Gram-positive) and Escherichia coli (Gram-negative) and reported in terms of mm. However, the test was performed in the agar medium with the positive (chloramphenicol) and negative controls (DMF). The disc of 6 $\mathrm{mm}$ was dipped into the compounds that were placed onto the sterilized nutrient agar medium inoculated with microorganisms. Then, each plate was incubated at $37^{\circ} \mathrm{C}$ for $24 \mathrm{~h}$, the zone of inhibition was measured.

\section{Nuclease activity on pUC18 DNA}

The extent of DNA cleavage activity of SC pUC18 DNA on thiosemicarbazone ligands and copper(II) complexes was monitored using agarose gel electrophoresis [11] in $5 \mathrm{mM}$ Tris- $\mathrm{HCl} / 50 \mathrm{mM} \mathrm{NaCl}$ buffer ( $\mathrm{pH}$ 7.2) in the presence of ascorbic acid and incubated for $1 \mathrm{~h}$. The test samples were electrophoresed with SC pUC18 DNA by varying the concentration $(40,60 \mu \mathrm{M})$. It was loaded on $1.2 \%$ agarose containing $0.5 \mathrm{mg} / \mathrm{mL}$ EB with loading buffer of $25 \%$ bromophenol blue, $0.25 \%$ xylene cyanol, and $30 \%$ glycerol for $1 \mathrm{~h}$. Later, DNA cleavage efficiency of SC DNA (Form I) to NC DNA (Form II) and linear (Form III) was examined and photographed by Spectroline UV transilluminator (UVITEC GeNeiTM Fire reader, India) gel documentation system.

\section{EXPERIMENTAL}

Synthesis of thiosemicarbazone ligands H(L1) - H(L3)

Synthesis of N-methyl-2-((1-methyl-1H-pyrrol-2-yl)methylene)hydrazine carbothioamide H(L1)

1-methyl-2-pyrrole carboxaldehyde $(0.10 \mathrm{~g}, 10 \mathrm{mmol})$ in a hot ethanolic solution, and 4-methyl-3-thiosemicarbazide $(0.10 \mathrm{~g}, 10 \mathrm{mmol})$ in water $(30 \mathrm{ml})$, and glacial acetic acid $(2 \mathrm{ml})$ were added dropwise and refluxed. After refluxing the above solution for $2 \mathrm{~h}$ on a water bath at $90^{\circ} \mathrm{C}$, the solution was kept allowed to stand overnight at room temperature until a yellow precipitate was separated out. Thus, the yellow precipitate obtained was washed thoroughly with cold ethanol and dried in vacuo over anhydrous $\mathrm{CaCl}_{2}$. It was then recrystallized from chloroform. Color: Yellow; color: Yellow; yield: $60 \%$; m.p $116-118^{\circ} \mathrm{C}$; Anal. Calcd for: $\mathrm{C}_{8} \mathrm{H}_{12} \mathrm{~N}_{4} \mathrm{~S}$ : C, 48.96; $\mathrm{H}, 6.16$; N, 28.55; $\mathrm{S} 16.34 \%$; found: C, 48.92; H, 6.14; N, 28.61; S, 16.35\%; $\Lambda_{\mathrm{m}}\left(\Omega^{-1} \mathrm{~cm}^{2} \mathrm{~mol}^{-1}\right)$ : 9; ${ }^{1} \mathrm{H}$ nuclear magnetic resonance (NMR) $\left(300 \mathrm{MHz}, \mathrm{CDCl}_{3}\right): \delta_{\mathrm{H}} 9.72(\mathrm{~d}, J=6.0 \mathrm{~Hz}$, $1 \mathrm{H}), 7.93(\mathrm{~d}, J=6.0 \mathrm{~Hz}, 1 \mathrm{H}), 7.38(\mathrm{~s}, 1 \mathrm{H}), 6.87(\mathrm{~s}, 1 \mathrm{H}), 6.66(\mathrm{~d}, J=2.1 \mathrm{~Hz}$, $1 \mathrm{H}), 6.29(\mathrm{~s}, 1 \mathrm{H}), 3.96(\mathrm{~s}, 3 \mathrm{H}), 3.37-3.36(\mathrm{~m}, 3 \mathrm{H}) ;{ }^{13} \mathrm{C}$ NMR $(75 \mathrm{MHz}$, $\left.\mathrm{CDCl}_{3}\right): \delta_{\mathrm{C}} 177.7,136.5,128.6,126.5,116.4,109.4,37.0,31.6$; FT-IR (KBr; cm-1): $3148(\mathrm{~s}, \mathrm{NH}), 1595(\mathrm{~s}, \mathrm{C}=\mathrm{N}), 757$ (s, C=S), 937 (s, N-N) (s, strong; m, medium); UV-Vis: $\lambda_{\max }$ (DMF) nm: 235,350 . The similar method was applied for the synthesis of H(L2) and H(L3) using 4-ethyl3-thiosemicarbazide and 4-phenyl-3-thiosemicarbazide instead of 4-methyl-3-thiosemicarbazide.

Synthesis of N-ethyl-2-((1-methyl-1H-pyrrol-2-yl)methylene)hydrazine carbothioamide $H(L 2)$

Color: Yellow; yield: $76 \%$; m.p $119-121^{\circ} \mathrm{C}$; Anal. Calcd for: $\mathrm{C}_{13} \mathrm{H}_{14} \mathrm{~N}_{4} \mathrm{~S}$ : C, 51.40; H, 6.71; N, 26.64; S 15.25\%; found: C, 51.37; H, 6.74; N, 26.72;
S, $15.37 \% ; \Lambda_{\mathrm{m}}\left(\Omega^{-1} \mathrm{~cm}^{2} \mathrm{~mol}^{-1}\right): 4 ;{ }^{1} \mathrm{H}$ NMR $\left(300 \mathrm{MHz}, \mathrm{CDCl}_{3}\right) \delta_{\text {н }} 10.20(\mathrm{~s}$, $1 \mathrm{H}), 8.04(\mathrm{~s}, 1 \mathrm{H}), 7.41(\mathrm{~s}, 1 \mathrm{H}), 6.89(\mathrm{~s}, 1 \mathrm{H}), 6.69(\mathrm{~s}, 1 \mathrm{H}), 6.31(\mathrm{~s}, 1 \mathrm{H})$, $3.97(\mathrm{~s}, 3 \mathrm{H}), 3.90-3.86(\mathrm{~m}, 2 \mathrm{H}), 1.44(\mathrm{t}, J=6.0 \mathrm{~Hz}, 3 \mathrm{H}) ;{ }^{13} \mathrm{C} \mathrm{NMR}(75 \mathrm{MHz}$, $\left.\mathrm{CDCl}_{3}\right): \delta_{\mathrm{c}} 176.5,136.5,128.5,127.0,116.2,109.4,39.6,36.9,15.1$; FTIR (KBr; $\mathrm{cm}^{-1}$ ): 3188 (s, NH), 1557 (s, C=N), 760 (m, C=S); UV-Vis: $\lambda_{\max }$ (DMF) nm: 275, 330.

Synthesis of 2-((1-methyl-1H-pyrrol-2-yl)methylene)-N-phenylhydrazine carbothioamide $H(L 3)$

Color: Yellow; 74\%; m.p 120-122 ${ }^{\circ} \mathrm{C}$; Anal. Calcd for: $\mathrm{C}_{13} \mathrm{H}_{14} \mathrm{~N}_{4} \mathrm{~S}$ : C, 60.44; H, 5.46; N, 21.69; S 12.41\%; found: C, 60.37; H, 5.49; N, 21.72; S, $12.37 \% ; \Lambda_{\mathrm{m}}\left(\Omega^{-1} \mathrm{~cm}^{2} \mathrm{~mol}^{-1}\right): 6$; ${ }^{1} \mathrm{H}$ NMR (300 $\left.\mathrm{MHz}, \mathrm{CDCl}_{3}\right)$ : $\delta_{\mathrm{H}} 10.84(\mathrm{~d}, J=12.0 \mathrm{~Hz}, 1 \mathrm{H}), 8.03(\mathrm{~d}, J=3.0 \mathrm{~Hz}, 1 \mathrm{H}), 7.98(\mathrm{~s}, 1 \mathrm{H}), 7.47$ (d, $J=3.0 \mathrm{~Hz}, 1 \mathrm{H}), 7.42(\mathrm{~s}, 1 \mathrm{H}), 6.95(\mathrm{~s}, 1 \mathrm{H}), 6.91(\mathrm{~s}, 1 \mathrm{H}), 6.74(\mathrm{~s}$, $1 \mathrm{H}), 6.71-6.69(\mathrm{~m}, 1 \mathrm{H}), 6.36(\mathrm{~s}, 1 \mathrm{H}), 6.33-6.31(\mathrm{~m}, 1 \mathrm{H}), 4.05-3.85$ $(\mathrm{m}, 3 \mathrm{H}) ;{ }^{13} \mathrm{C}$ NMR $\left(75 \mathrm{MHz}, \mathrm{CDCl}_{3}\right): \delta_{\mathrm{C}} 176.5,139.2,136.5,132.2$, 129.1, 128.5, 127.0, 126.5, 126.0, 122.4, 116.2, 109.4, 39.6; FT-IR $\left(\mathrm{KBr} ; \mathrm{cm}^{-1}\right): 3188(\mathrm{~s}, \mathrm{NH}), 1557(\mathrm{~s}, \mathrm{C}=\mathrm{N}), 837$ (m, C=S); UV-Vis: $\lambda_{\max }$ (DMF) nm: 240, 365 .

\section{Synthesis of copper(II) bis complexes (1-3)}

To a hot ethanolic solution of ligands H(L1) - H(L3) (1 mmol), an ethanolic solution of copper(II) chloride dihydrate ( $2 \mathrm{mmol}$ ) was added dropwise with constant stirring for $1 \mathrm{~h}$. The resulting green solution obtained was allowed to stand overnight. Later, green precipitate formed was collected by filtration, washed thoroughly with ethanol and dried in vacuo over anhydrous $\mathrm{CaCl}_{2}$. The similar method was applied for the synthesis of complexes 2 and 3 using H(L2) and H(L3) instead of H(L1). The schematic representation of synthesis of copper(II) bis complexes is given in Scheme 1.

$\left[\mathrm{Cu}(\mathrm{L} 1)_{2}\right](1)$

Color: Green; 70\%; Anal. Calcd for: $\mathrm{C}_{16} \mathrm{H}_{2} \mathrm{CuN}_{8} \mathrm{~S}_{2}$ : C, 42.32; H, 4.88; N, 24.68; S, 14.12\%; found: C, 42.40; H, 4.79; N, 24.71; S, 14.16\%; $\Lambda_{\mathrm{m}}$ $\left(\Omega^{-1} \mathrm{~cm}^{2} \mathrm{~mol}^{-1}\right): 23$; FT-IR $\left(\mathrm{KBr} ; \mathrm{cm}^{-1}\right): 3117(\mathrm{~s}, \mathrm{NH}), 1572(\mathrm{~s}, \mathrm{C}=\mathrm{N}), 735$ $(\mathrm{s}, \mathrm{C}-\mathrm{S}), 1028(\mathrm{~m}, \mathrm{~N}-\mathrm{N}), 442(\mathrm{~m}, \mathrm{Cu}-\mathrm{N})$ and $565(\mathrm{~s}, \mathrm{Cu}-\mathrm{S}) ; \mathrm{UV}-\mathrm{Vis}: \lambda_{\max }$ (DMF) nm: 305, 360, $630\left(\mathrm{~d}-\mathrm{d}\right.$ transition); EPR: $\mathrm{A}_{\|}=163 \times 10^{-4} \mathrm{~cm}^{-1}$; $\mathrm{g}_{\|}=2.261 ; \mathrm{g}_{\perp}=2.062 ; \mathrm{g}_{\|} / \mathrm{A}_{\|}=139 \mathrm{~cm} ; \mathrm{G}=4.21$.

[Cu(L2) $\left.)_{2}\right](2)$

Color: Green; yield: 70\%; Anal. Calcd for: $\mathrm{C}_{18} \mathrm{H}_{26} \mathrm{CuN}_{8} \mathrm{~S}$ : C, 44.84; H, 5.44; N, 23.24; S, 13.30\%; found: C, 44.81; H, 5.48; N, 23.29; S, 13.28\%. $\Lambda_{\mathrm{m}}$ $\left(\Omega^{-1} \mathrm{~cm}^{2} \mathrm{~mol}^{-1}\right): 24$; FT-IR $\left(\mathrm{KBr} ; \mathrm{cm}^{-1}\right): 2974(\mathrm{~m}, \mathrm{NH}), 1560(\mathrm{~s}, \mathrm{C}=\mathrm{N})$, $858(\mathrm{~s}, \mathrm{C}-\mathrm{S}), 1042(\mathrm{~m}, \mathrm{~N}-\mathrm{N}), 418(\mathrm{~m}, \mathrm{Cu}-\mathrm{N})$ and $642(\mathrm{~s}, \mathrm{Cu}-\mathrm{S}) ; \mathrm{UV}-\mathrm{Vis}$ : $\lambda_{\max }(D M F) \mathrm{nm}: 295,350,555$ (d-d transition); EPR: $\mathrm{A}_{\|}=164 \times 10^{-4} \mathrm{~cm}^{-1}$; $\mathrm{g}_{\|}=2.258 ; \mathrm{g}_{\perp}=2.061 ; \mathrm{g}_{||} / \mathrm{A}_{\|}=137 \mathrm{~cm} ; \mathrm{G}=4.22$.

\section{$\left[\mathrm{Cu}(\mathrm{L} 3)_{2}\right](3)$}

Color: Green; yield: 74\%; Anal. Calcd for: $\mathrm{C}_{26} \mathrm{H}_{26} \mathrm{CuN}_{8} \mathrm{~S}$ : C, 54.01; H, 4.53; N, 19.38; S, 11.09\%; found: C, 54.05; H, 4.61; N, 19.35; S, 11.05\%. $\Lambda_{\mathrm{m}}$ $\left(\Omega^{-1} \mathrm{~cm}^{2} \mathrm{~mol}^{-1}\right): 20.19$; FT-IR (KBr; cm$\left.{ }^{-1}\right): 3117(\mathrm{~s}, \mathrm{NH}), 1572$ (s, C=N), $814(\mathrm{~m}, \mathrm{C}-\mathrm{S}), 1028(\mathrm{~m}, \mathrm{~N}-\mathrm{N}), 429(\mathrm{~m}, \mathrm{Cu}-\mathrm{N})$ and 565 (s, Cu-S); UV-Vis: $\lambda_{\max }(D M F) \mathrm{nm}: 300,360,560$ (d-d transition); EPR: $\mathrm{A}_{\|}=164 \times 10^{-4} \mathrm{~cm}^{-1}$; $\mathrm{g}_{\|}=2.264 ; \mathrm{g}_{\perp}=2.067 ; \mathrm{g}_{\|} / \mathrm{A}_{\|}=138 \mathrm{~cm} ; \mathrm{G}=3.94$.

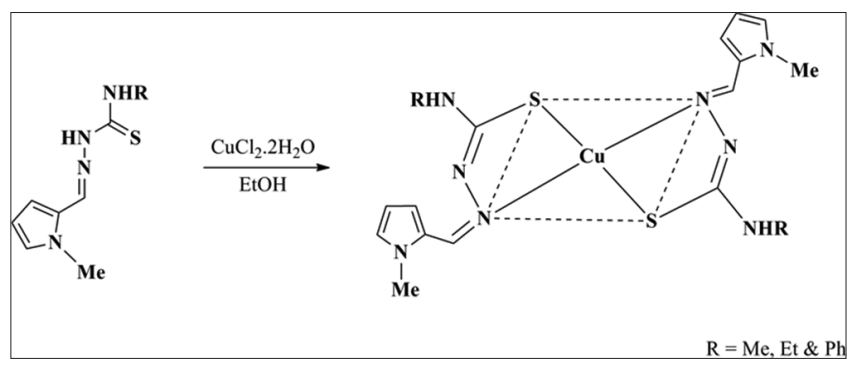

Scheme 1: Schematic representation of synthesis of copper(II) bis complexes 1-3 
Synthesis of mixed ligand copper(II) complexes (4-9)

To a hot ethanolic solution of ligand H(L1) (1 mmol), an ethanolic solution of diimine coligands (bpy/phen) was added dropwise with constant stirring for $1 \mathrm{~h}$. To this resulting yellow solution copper(II) chloride dihydrate $(2 \mathrm{mmol})$ in ethanol was added and the stirring was continued for about an hour. The resulting green solution was allowed to stand overnight. Later, green precipitate formed was collected by filtration, washed thoroughly with ethanol and dried in vacuo over anhydrous $\mathrm{CaCl}_{2}$. The schematic representation of synthesis of mixed ligand copper(II) complexes is given in Scheme 2.

$\left[\mathrm{Cu}\left(\mathrm{L}_{1}\right)(\mathrm{bpy})\right] \mathrm{Cl}(4)$

Color: Green; yield: 62\%; Anal.Calcd for: $\mathrm{C}_{18} \mathrm{H}_{19} \mathrm{ClCuN}_{6} \mathrm{~S}$ : C, 48.00; H, 4.25; N, 18.66; S, 7.12\%; found: C, 47.98; H, 4.29; N, 18.74; S, 7.18\%. $\Lambda_{\mathrm{m}}\left(\Omega^{-1} \mathrm{~cm}^{2} \mathrm{~mol}^{-1}\right): 59 ; \mathrm{FT}-\mathrm{IR}\left(\mathrm{KBr} ; \mathrm{cm}^{-1}\right): 3113(\mathrm{~s}, \mathrm{NH}), 1570(\mathrm{~s}, \mathrm{C}=\mathrm{N})$, 735 (s, C-S), $1024(\mathrm{~s}, \mathrm{~N}-\mathrm{N}), 422(\mathrm{~m}, \mathrm{Cu}-\mathrm{N})$ and 565 (s, Cu-S); UV-Vis: $\lambda_{\max }$ (DMF) nm: 315, 365, 580 (d-d transition); EPR: $A_{\|}=165 \times 10^{-4} \mathrm{~cm}^{-1}$; $\mathrm{g}_{\|}=2.260 ; \mathrm{g}_{\perp}=2.069 ; \mathrm{g}_{\|} / \mathrm{A}_{\|}=136 \mathrm{~cm} ; \mathrm{G}=3.77$.

$\left[\mathrm{Cu}\left(\mathrm{L}_{2}\right)(\mathrm{bpy})\right] \mathrm{Cl}(5)$

Color: Green; yield: 79\%; Anal.Calcd for: $\mathrm{C}_{19} \mathrm{H}_{21} \mathrm{ClCuN}_{6} \mathrm{~S}_{2}: \mathrm{C}, 49.13 ; \mathrm{H}$, 4.56; N, 18.09; S, 6.90\%; found: C, 49.24; H, 4.61; N, 18.14; S, 6.83\%. $\Lambda_{\mathrm{m}}\left(\Omega^{-1} \mathrm{~cm}^{2} \mathrm{~mol}^{-1}\right): 69 ; \mathrm{FT}-\mathrm{IR}\left(\mathrm{KBr} ; \mathrm{cm}^{-1}\right): 3107(\mathrm{~s}, \mathrm{NH}), 1568(\mathrm{~s}, \mathrm{C}=\mathrm{N})$, $806(\mathrm{~s}, \mathrm{C}-\mathrm{S}), 1022(\mathrm{~s}, \mathrm{~N}-\mathrm{N}), 416(\mathrm{~s}, \mathrm{Cu}-\mathrm{N})$ and 635 (s, Cu-S); UV-Vis: $\lambda_{\text {max }}$ (DMF) nm: 340, 395, 720 (d-d transition); EPR: $A_{\|}=162 \times 10^{-4} \mathrm{~cm}^{-1}$; $\mathrm{g}_{\|}=2.257 ; \mathrm{g}_{\perp}=2.064 ; \mathrm{g}_{\|} / \mathrm{A}_{\|}=139 \mathrm{~cm} ; \mathrm{G}=4.01$

$\left[\mathrm{Cu}\left(\mathrm{L}_{3}\right)(\mathrm{bpy})\right] \mathrm{Cl}(6)$

Color: Green; yield: 60\%; Anal. Calcd for: $\mathrm{C}_{23} \mathrm{H}_{21} \mathrm{ClCuN}_{6} \mathrm{~S}$ : C, 53.90; H, 4.13; N, 16.40; S, 6.26\%; Found: C, 53.84; H, 4.17; N, 16.35; S, 6.20\%; $\Lambda_{\mathrm{m}}\left(\Omega^{-1} \mathrm{~cm}^{2} \mathrm{~mol}^{-1}\right): 77$; FT-IR $\left(\mathrm{KBr} ; \mathrm{cm}^{-1}\right): 3167(\mathrm{~m}, \mathrm{NH}), 1568(\mathrm{~s}, \mathrm{C}=\mathrm{N})$, 775 (s, C-S), $1022(\mathrm{~s}, \mathrm{~N}-\mathrm{N}), 419(\mathrm{~s}, \mathrm{Cu}-\mathrm{N})$ and 635 (s, Cu-S); UV-Vis: $\lambda_{\max }(D M F) \mathrm{nm}: 295,380,595$ (d-d transition); EPR: $A_{\|}=164 \times 10^{-4} \mathrm{~cm}^{-1}$; $\mathrm{g}_{\|}=2.269 ; \mathrm{g}_{\perp}=2.067 ; \mathrm{g}_{\|} / \mathrm{A}_{\|}=138 \mathrm{~cm} ; \mathrm{G}=4.01$.

$\left[\mathrm{Cu}\left(\mathrm{L}_{1}\right)(\right.$ phen $\left.)\right] \mathrm{Cl}(7)$

Color: Green; yield: 78\%; Anal. Calcd for: $\mathrm{C}_{20} \mathrm{H}_{19} \mathrm{ClCuN}_{6} \mathrm{~S}$ : C, 50.63; $\mathrm{H}$, 4.04; N, 17.71; S, 6.76\%; found: C, 50.57; H, 4.09; N, 17.78; S, 6.79\%. $\Lambda_{1}\left(\Omega^{-1} \mathrm{~cm}^{2} \mathrm{~mol}^{-1}\right): 82 ; \mathrm{FT}-\mathrm{IR}\left(\mathrm{KBr} ; \mathrm{cm}^{-1}\right): 3117(\mathrm{~s}, \mathrm{NH}), 1572(\mathrm{~s}, \mathrm{C}=\mathrm{N})$, 735 (s, C-S), $1086(\mathrm{~m}, \mathrm{~N}-\mathrm{N}), 438(\mathrm{~m}, \mathrm{Cu}-\mathrm{N})$ and $565(\mathrm{~s}, \mathrm{Cu}-\mathrm{S})$; UV-Vis: $\lambda_{\max }(\mathrm{DMF}) \mathrm{nm}: 310,365,590$ (d-d transition); EPR: $\mathrm{A}_{\|}=163 \times 10^{-4} \mathrm{~cm}^{-1}$; $\mathrm{g}_{\|}=2.259 ; \mathrm{g}_{\perp}=2.066 ; \mathrm{g}_{\|} / \mathrm{A}_{\|}=139 \mathrm{~cm} ; \mathrm{G}=3.92$.

$\left[\mathrm{Cu}\left(\mathrm{L}_{2}\right)(\right.$ phen $\left.)\right] \mathrm{Cl}(8)$

Color: Green; yield: 75\%; Anal. Calcd for: $\mathrm{C}_{21} \mathrm{H}_{21} \mathrm{ClCuN}_{6} \mathrm{~S}$ : C, 51.63; H, 4.33; N, 17.20; S, 6.56\%; found: C, 51.66; H, 4.28; N, 17.17; S, 6.59\%. $\Lambda_{\mathrm{m}}\left(\Omega^{-1} \mathrm{~cm}^{2} \mathrm{~mol}^{-1}\right): 62$; FT-IR $\left(\mathrm{KBr} ; \mathrm{cm}^{-1}\right): 3052(\mathrm{~s}, \mathrm{NH}), 1582(\mathrm{~s}, \mathrm{C}=\mathrm{N})$, $854(\mathrm{~s}, \mathrm{C}-\mathrm{S}), 1047(\mathrm{~m}, \mathrm{~N}-\mathrm{N}), 428(\mathrm{~s}, \mathrm{Cu}-\mathrm{N})$ and $644(\mathrm{~s}, \mathrm{Cu}-\mathrm{S})$; UV-Vis: $\lambda_{\text {max }}$ (DMF) nm: 315, 355, 725 (d-d transition); EPR: $A_{\|}=164 \times 10^{-4} \mathrm{~cm}^{-1}$; $\mathrm{g}_{\|}=2.254 ; \mathrm{g}_{\perp}=2.060 ; \mathrm{g}_{\|} / \mathrm{A}_{\|}=137 \mathrm{~cm} ; \mathrm{G}=4.23$.

$\left[\mathrm{Cu}\left(\mathrm{L}_{3}\right)\right.$ (phen) $] \mathrm{Cl}(9)$

Color: Green; yield: 76\%; Anal. Calcd for: $\mathrm{C}_{25} \mathrm{H}_{21} \mathrm{ClCuN}_{6} \mathrm{~S}_{2}$ : C, 55.96; $\mathrm{H}$, 3.95; N, 14.69; S, 5.98\%; found: C, 55.89; H, 3.90; N, 15.72; S, 5.94\%; $\Lambda \quad\left(\Omega^{-1} \mathrm{~cm}^{2} \mathrm{~mol}^{-1}\right): 81$; FT-IR $\left(\mathrm{KBr} ; \mathrm{cm}^{-1}\right): 3053(\mathrm{~m}, \mathrm{NH}), 1581(\mathrm{~s}, \mathrm{C}=\mathrm{N})$, $854(\mathrm{~s}, \mathrm{C}-\mathrm{S}), 1047(\mathrm{~m}, \mathrm{~N}-\mathrm{N}), 428(\mathrm{~m}, \mathrm{Cu}-\mathrm{N})$ and $644(\mathrm{~s}, \mathrm{Cu}-\mathrm{S})$; UV-Vis: $\lambda_{\max }(\mathrm{DMF}) \mathrm{nm}$ : 380, 560, 735 (d-d transition); EPR: $\mathrm{A}_{\|}=163 \times 10^{-4} \mathrm{~cm}^{-1}$; $\mathrm{g}_{\|}=2.268 ; \mathrm{g}_{\perp}=2.069 ; \mathrm{g}_{\|} / \mathrm{A}_{\|}=139 \mathrm{~cm} ; \mathrm{G}=3.88$.

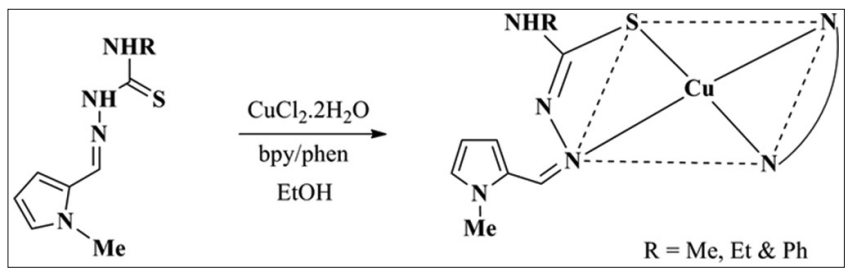

Scheme 2: Schematic representation of synthesis of mixed ligand copper(II) complexes

\section{RESULTS AND DISCUSSION}

${ }^{1} \mathrm{H}$ and ${ }^{13} \mathrm{C}$ NMR of thiosemicarbazone ligands H(L1) - H(L3)

The ${ }^{1} \mathrm{H}$ and ${ }^{13} \mathrm{C}$ NMR spectra of the free thiosemicarbazone ligands were recorded in $\mathrm{CDCl}_{3}$ using TMS as an internal standard. The ${ }^{1} \mathrm{H}$ NMR spectra of ligand H(L2) showed signals hydrazinic proton around at $\delta 9.50 \mathrm{ppm}$ for all methyl and ethyl substituted thiosemicarbazone ligands H(L1) and H(L2), which was absent in H(L3). This might be due to the existence of the electron withdrawing phenyl substituent at the terminal nitrogen that eventually shifted the labeled peak toward the downfield region $(\delta 10.8 \mathrm{ppm})$ compared to other thiosemicarbazone ligands [12]. The chemical shifts of the aromatic protons of phenyl substituted thiosemicarbazone appeared around $\delta 6.45-8.50 \mathrm{ppm}$ and the rest of the methyl and ethyl substituted thiosemicarbazone ligands appeared below $\delta 6.0 \mathrm{ppm}$ [13]. In the ${ }^{13} \mathrm{C} N M R$ of the thiosemicarbazone ligands showed aromatic carbon signals in the upfield region, whereas chemical shifts of $\mathrm{C}=\mathrm{S}$ and $\mathrm{C}=\mathrm{N}$ found near $\delta 165$ and $145 \mathrm{ppm}$, respectively [14]. In addition, the chemical shift of methyl and ethyl carbon of substituted thiosemicarbazone ligands appeared in the region of $\delta 31.6$ and $\delta 15.1 \mathrm{ppm}$, respectively.

\section{Electronic spectra}

The UV-Vis measurement of the synthesized thiosemicarbazone ligands and their copper(II) complexes in the $1 \times 10^{-3} \mathrm{M}$ concentration in DMF was performed in the wavelength range 200-1000 nm. The absorption bands of thiosemicarbazone ligands showed two intense bands close to 280 and $350 \mathrm{~nm}$ and designated as $\pi \rightarrow \pi *$ and $n \rightarrow \pi *$, respectively. The low energy band at $280 \mathrm{~nm}$ associated with the imine group of thiosemicarbazone. This band has undergoes a bathochromic shift in the spectra of the thiosemicarbazone copper(II) complexes as a result of the donation of the lone pair of electrons to the central metal ion [15]. While the band at $300-330 \mathrm{~nm}$ has suffered a blue shift in copper(II) complexes as a result of thioenolization. These shifts in the spectra of the complexes yet again proved the coordination of azomethine nitrogen and thioamide function to copper. Moreover, all the thiosemicarbazone copper(II) complexes exhibited much significant characteristics $\mathrm{d}-\mathrm{d}$ band at $600-700 \mathrm{~nm}$ due to ${ }^{2} \mathrm{~B}_{1 \mathrm{~g}} \rightarrow{ }^{2} \mathrm{~B}_{2 \mathrm{~g}^{\prime}}$ ${ }^{2}$ Eg transitions (Fig. 1) [16]. From the electronic spectral data square planar geometry was proposed for all the thiosemicarbazone copper(II) complexes.

\section{FT-IR spectroscopy}

The most useful main functionalities of the free thiosemicarbazone ligands H(L1) - H(L3) and copper(II) complexes 1-9 were established by FT-IR spectroscopy. The FT-IR spectra of uncomplexed thiosemicarbazone ligands showed the band around at $820 \mathrm{~cm}^{-1}$ attributable to the presence of $\mathrm{v}(\mathrm{C}=\mathrm{S})$ in the solid state. In thiosemicarbazone copper(II) complexes, $\mathrm{v}(\mathrm{C}=\mathrm{S})$ disappeared as a result of deprotonation of hydrazinic proton of $\mathrm{v}(\mathrm{N}(2)-\mathrm{H})$ by thioenolization

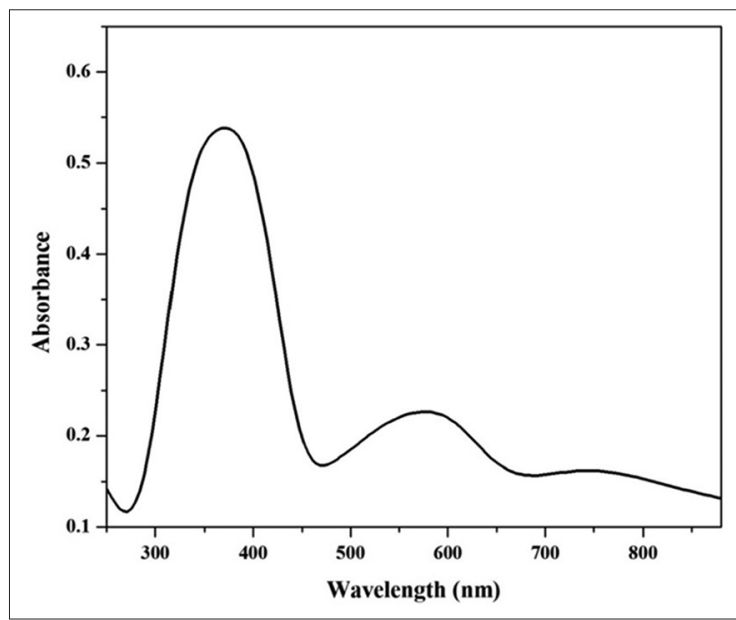

Fig. 1: Electronic spectra of complex 9 in DMF 
$(-\mathrm{NH}-\mathrm{C}(\mathrm{S})$ to $-\mathrm{N}=\mathrm{C}(\mathrm{SH}))$. The deprotonation and coordination could also be substantiated by the existence of a new medium $\mathrm{C}=\mathrm{N}-\mathrm{N}=\mathrm{C}$ and $\mathrm{C}-\mathrm{S}$ vibrations near 1530 and $750 \mathrm{~cm}^{-1}$, respectively, and afforded strong proof for the coordination of deprotonated thiolate sulfur to copper. The azomethine vibration of ligand H(L1) at $1525 \mathrm{~cm}^{-1}$ shifted to $1595 \mathrm{~cm}^{-1}$ on chelation indicating coordination of imine bond to the copper $[17,18]$, whereas a sharp band observed at $970 \mathrm{~cm}^{-1}$ assignable to $\mathrm{v}(\mathrm{N}-\mathrm{N})$ of thiosemicarbazone ligands. This characteristics band was shifted to higher frequencies by $15-20 \mathrm{~cm}^{-1}$ on complexation due to the increases in the double bond character and loss of electron density by donation to the copper [19]. Similar changes were observed for all other complexes. The appearance of new weak intensity bands at $423-461 v(\mathrm{Cu}-\mathrm{N})$ and $592-643 v(\mathrm{Cu}-\mathrm{S})$ yet again confirms the nature of the copper-ligand bonding. Hence, these above observations evidently indicated that the mode of coordination of thiosemicarbazone to copper has good agreement with the structures of the complexes proposed by EPR.

\section{EPR spectra}

The EPR parameters of the bis copper(II) complexes 1-3 and mixed ligand copper(II) complexes 4-9 in DMF were recorded at room temperature as well as liquid nitrogen temperature $(77 \mathrm{~K})$ on the $\mathrm{X}$-band EPR at frequency $9.1 \mathrm{GHz}$. The room temperature and frozen $\mathrm{X}$-band EPR spectra of the complexes were quite similar and showed axial type g-tensor parameter with $\mathrm{g}_{\|}>\mathrm{g}_{>}>2.0023$ designated that the presence of one unpaired electron in $\mathrm{d}_{\mathrm{x}-\mathrm{y}}^{2}$ orbital of ${ }^{2} \mathrm{~B}_{1 \mathrm{~g}}$ ground state. In addition to this, the exchange interaction parameter of $\mathrm{G}$ could be obtained by the following expression: $\left.G=\left[\mathrm{g}_{\|}-2\right) /\left(\mathrm{g}_{\perp-2}\right)\right]=3.7-4.6$. When the $G>4$ indicating exchange interaction in solid copper(II) center was negligible, if $\mathrm{G}<4$ indicating considerable exchange interaction in the copper(II) complexes. In all the copper(II) complexes, the G value found within 3.77-4.23, specified negligible exchange coupling effect. In Addition, $\mathrm{g}_{\|}$afforded valuable information regarding the nature of the metal-ligand bonding $[18,19]$. According to Hathaway [21], for an ionic environment $g_{\|}$of the copper(II) complexes have been usually $\geq 2.3$ but the value was $<2.3$ suggesting a covalent environment of the copper(II) complexes [20] while $g_{\|}$value of the synthesized complexes was achieved $<2.3$ signify the covalent character of the copper-ligand bonding. In the X-band EPR spectra of the complexes showed a quartet hyperfine splitting at the $\mathrm{g}_{\|}$region and corresponding to the nuclear spin $(\mathrm{I}=3 / 2)$. Therefore, the obtained $\mathrm{g}_{\|}(2.260)>\mathrm{g}_{\wedge}(2.069)>2.0023$ of complex 4 (Fig. 2), signify that the copper ion lies in $d_{x-y}^{2}{ }^{2}$ which indicates the characteristics of square planar geometry.

In general, $\mathrm{CuN}_{4}$ chromophore of square-based geometry was expected to show $g_{\|}$and $A_{\|}$values around 2.200 and $180-200 \times 10^{-4}$ [22]. However, the synthesized thiosemicarbazone copper(II) bis complexes and mixed ligand copper(II) complexes displayed $g_{\|}$ $(2.258-2.264,2.260-2.268)$ and $A_{\|}(163-164,163-165)$, respectively. These increases in the $g_{\|}$and decreases in the $A_{\|}$value possibly due to the replacement of two coordinated nitrogen by two molecules of sulfur. Hence, the observed values reliable with the $\mathrm{CuN}_{2} \mathrm{~S}_{2}$ and $\mathrm{CuN}_{3} \mathrm{~S}$ chromophore of bis complexes and mixed ligand copper(II) complexes. This was further supported by the value of $f=g_{\|} / A_{\|}$quotient (where $f$ is the index of tetragonal distortion) fall within the range of $130-138 \times 10^{-4}$ $\mathrm{cm}$ characteristics of square planar geometry. Here, the obtained $f$ value of the copper(II) complexes from $136-139 \times 10^{-4} \mathrm{~cm}$ indicating perfect square planar geometry [23]. This was yet again supported by the neutral and 1:1 electrolyte nature of the thiosemicarbazone copper(II) complexes [24].

\section{Pharmacological studies}

Antibacterial activity: Minimum inhibitory concentration

The antibacterial activity of the thiosemicarbazone copper(II) complexes was screened using disc diffusion by the determination of zone of inhibition for both Gram-positive and Gram-negative bacterial strains. All the test compounds showed different results against two different bacterial strains when compared to chloramphenicol. On the evaluation of the antibacterial screening showed that following:
- The results concerning E. coli, thiosemicarbazone copper(II) complexes showed moderate activity at $5 \mu \mathrm{g} / \mathrm{ml}$ concentration, and some of the mixed ligand complexes 7 and 8 displayed significant activity at higher concentration $(50 \mu \mathrm{g} / \mathrm{ml})$ than the bis copper(II) complexes under experimental conditions. Thus, the presence of phen/bpy considerably changes the antibacterial activity of the complexes

- At higher concentration, thiosemicarbazone complex 8 was strongly active and showed improved results in B. thuringiensis. However, the zone of inhibition of other copper(II) complexes was comparatively lower

- The positive results signified that on chelation the polarity of the copper(II) complexes reduced by partial sharing of positive charge with the donor groups over the chelating system. This was predominantly increased the lipophilic nature of the copper(II) complexes and accordingly terminating the growth of the microorganism by potent bacteriostatic effects $[25,26]$

- In view of that the other principle factors including, geometry, stability, and coordinating sites of the tested compounds which also enhances the antibacterial activity

- Hence, the present investigation revealed that the MIC values of the mixed ligand thiosemicarbazone complex eight against both bacterial strains were as effective at a maximum concentration and they need a higher concentration to wipe out the tested bacterial strains. This may possibly supportive to open up a novel pathway for developing new antibacterial drugs (Fig. 3).

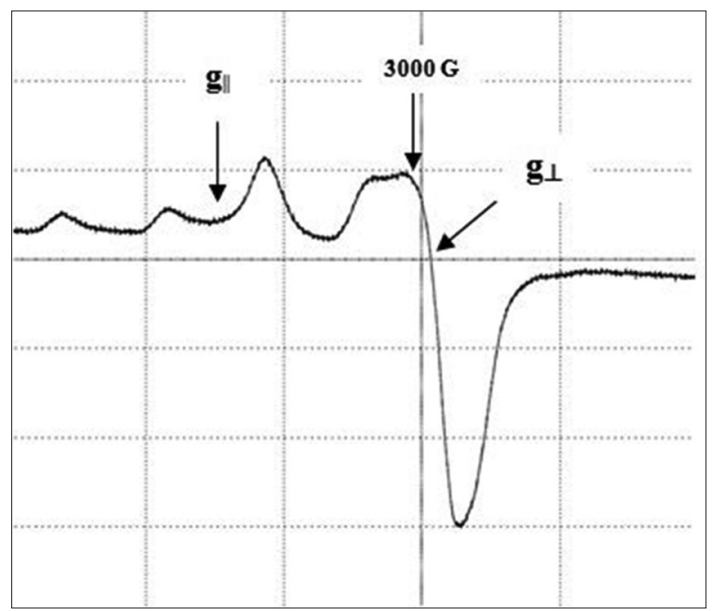

Fig. 2: X-band electron paramagnetic resonance spectra of complex 4 in frozen DMF

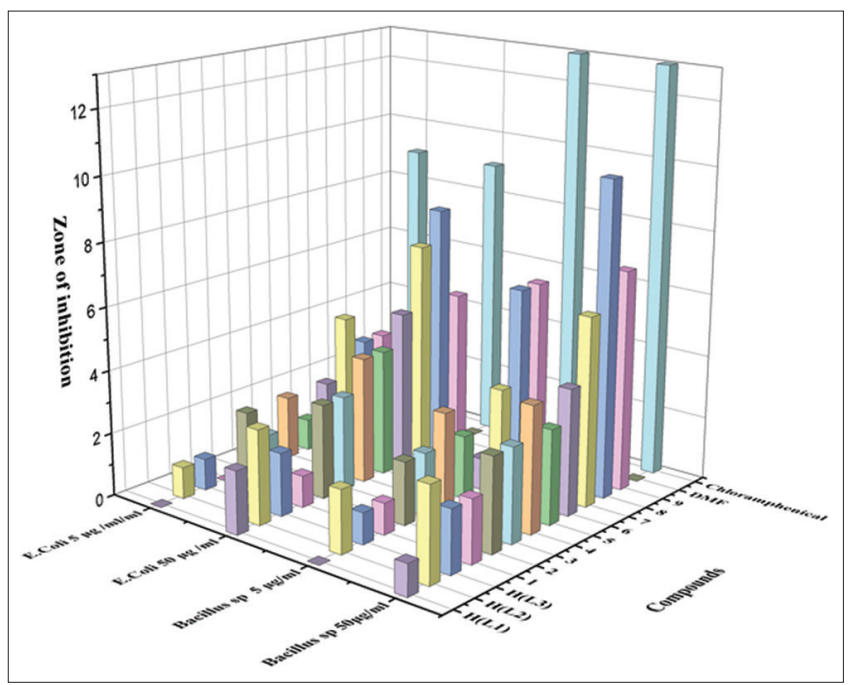

Fig. 3: The zone of inhibition of thiosemicarbazone ligands H(L1) - H(L3) and copper(II) complexes 1-9 


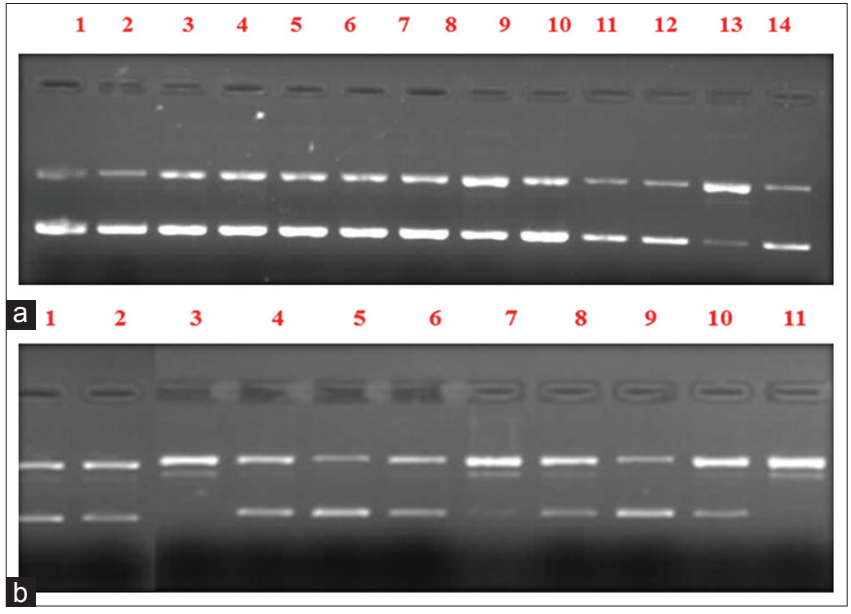

Fig. 4: (a) Gel electrophoresis of copper(II) complexes (40 $\mu \mathrm{M})$ in buffer containing $50 \mathrm{mM}$ Tri- $\mathrm{HCl} / 50 \mathrm{mM} \mathrm{NaCl}(\mathrm{pH} 7.2)$ in the presence of ascorbic acid at $37^{\circ} \mathrm{C}$. Lane 1: DNA control; Lane 2: DNA + ascorbic acid; Lane 3: DNA + Ligand H(L1) + ascorbic acid; Lane 4:DNA + [Cu(L1) $]+$ + ascorbic acid; Lane 5: DNA + [Cu(L1)(phen)]Cl + ascorbic acid; Lane 6: DNA + [Cu(L1)(bpy)]Cl + ascorbic acid; Lane 7: DNA+Ligand H(L3) + ascorbic acid; Lane 8:DNA + [Cu(L3) $]$ + ascorbic acid; Lane 9: DNA + [Cu(L3)(phen)] $\mathrm{Cl}+$ ascorbic acid; Lane 10: DNA + [Cu(L3)(bpy)]Cl + ascorbic acid; Lane 11: DNA+Ligand H(L2) + ascorbic acid; Lane 12: DNA $+\left[\mathrm{Cu}(\mathrm{L2})_{2}\right]+$ ascorbic acid; Lane 13: DNA + [Cu(L2)(phen) $] \mathrm{Cl}+$ ascorbic acid; Lane 14: DNA + [Cu(L2)(bpy)]Cl + ascorbic acid. (b) Gel electrophoresis of copper(II) complexes $(60 \mu \mathrm{M})$ in buffer containing $50 \mathrm{mM} \mathrm{Tri}-\mathrm{HCl} / 50 \mathrm{mM} \mathrm{NaCl}(\mathrm{pH} 7.2)$ in the presence of ascorbic acid at $37^{\circ} \mathrm{C}$. Lane 1: DNA + [Cu(L1) $]+$ ascorbic acid; Lane 3: DNA + [Cu(L1)(phen)]Cl + ascorbic acid; Lane 4: DNA + [Cu(L1)(bpy)]Cl + ascorbic acid; Lane 5: DNA+Ligand H(L3) + ascorbic acid; Lane 6: DNA + [Cu(L3) $\left.{ }_{2}\right]+$ ascorbic acid; Lane 7: DNA + [Cu(L3)(phen)]Cl + ascorbic acid; Lane 8: DNA + [Cu(L3)(bpy)]Cl + ascorbic acid; Lane 9: DNA+Ligand H(L2) + ascorbic acid; Lane 10: DNA + [Cu(L2) $]+$ ascorbic acid; and Lane 11: DNA + [Cu(L2)(phen) $] \mathrm{Cl}+$ ascorbic acid

Cleavage of pUC18 DNA by thiosemicarbazone copper(II) complexes

In recent years, many anticancer agents could be reported as a result of induced photocleavage activity by the strong DNA interaction and DNA strand scission. For this reason, the extent of DNA cleavage activity of thiosemicarbazone copper(II) complexes has been studied for the purpose of generating novel anticancer drug by triggering cell death via DNA damage. To identify the extent of DNA cleavage activity of the complexes 1-9 with SC pUC18 DNA was incubated with $5 \mathrm{mM}$ Tris- $\mathrm{HCl} / 50 \mathrm{mM} \mathrm{NaCl}(\mathrm{pH} 7.2)$ buffer with increasing concentrations 40-60 $\mu \mathrm{M}$ was studied using agarose gel electrophoresis. As seen in Fig. $4 \mathrm{a}$ and $\mathrm{b}$, there was no noticeable cleavage in control experiments (DNA and DNA with ascorbic acid). When the concentration-dependent DNA cleavage was performed at $40 \mu \mathrm{M}$ concentration with ascorbic acid, only a faint and moderate nuclease activity was noted under identical conditions. While complete DNA degradation was observed in complexes 7 and 8 which converts the SC DNA into undetectable minor fragments at $60 \mu \mathrm{M}$ concentration).

It is interesting to note that as the concentration increases the amount of Form I (SC DNA) decrease, whereas both Form II (NC DNA) and Form III (Linear) increases correspondingly. Moreover, the majority of the mixed ligand complexes exhibit efficient oxidative cleavage higher than copper(II) bis complexes. In addition, complexes with diimine co-ligands act as a DNA recognition element and engage strong DNA interaction with an extended aromatic ring of bpy and phen [27]. It was apparently due to the partial intercalation and deeper insertion of the diimine coligands would predominately increase the DNA cleavage activity [28]. These complexes were proper candidates to make an effort for the development of potential anticancer drugs.

\section{CONCLUSION}

In the present study, nine thiosemicarbazone copper(II) complexes 1-9 were synthesized and characterized by various spectro analytical techniques, and it was coordinated through azomethine nitrogen and thiolate sulfur through deprotonation. The EPR spectral studies confirmed that square planar geometry of the bis and mixed ligand copper(II) complexes. The biological activity of the compounds displayed a higher antibacterial activity for mixed ligand copper(II) complex 8 than bis complexes. This possibly due to the geometry and the effect of the existence of phen and $N(4)$-substituted thiosemicarbazide derivatives. Correspondingly, complex 8 completely degrade the SC pUC18DNA in the presence of the activating agent. Only fewer amounts of metal complexes with phen were reported as potential nuclease agent. Interestingly, the existing study revealed noteworthy nuclease activity on mixed ligand complex 8 by strong DNA interaction even at the minimum concentration $(60 \mu \mathrm{M})$. Conclusively, the significant biological activities of complex 8 have been further studied for the purpose of effective chemotherapeutic drug toward different cancer cells.

\section{ACKNOWLEDGMENT}

The authors express their honest thanks to the Principal, Lady Doak College and the management for providing research facilities. The authors thank SAIF, IIT Bombay for recording EPR spectra and also thank the Science Instrumentation Centre, Lady Doak College.

\section{AUTHOR'S CONTRIBUTIONS}

All authors have equally contributed to this work regarding experimental design, performing experiments, data completion, and progress of the manuscript.

\section{CONFLICTS OF INTEREST}

There are no conflicts of interest for all the authors regarding this article.

\section{REFERENCES}

1. Raja DS, Bhuvanesh NS, Natarajan K. Effect of N(4)-phenyl substitution in 2-oxo-1,2-dihydroquinoline-3-carbaldehyde semicarbazones on the structure, DNA/protein interaction, and antioxidative and cytotoxic activity of cu(II) complexes. Inorg Chem 2011:50:12852-66.

2. Yong L, Yang ZY, Wu JC. Synthesis, crystal structures, biological activities and fluorescence studies of transition metal complexes with 3-carbaldehyde chromone thiosemicarbazone. Eur J Med Chem 2010;12:5692-1.

3. Heloisa B, Boyd LP, West DX. Copper (II) and nickel (II) complexes of glyoxaldehyde bis $\{\mathrm{N}$ (3)-substituted thiosemicarbazones\}. Transit Met Chem 1997;23:67-71.

4. Chandra S, Vandana S. Synthesis, spectroscopic, anticancer and antibacterial studies of ni(II) and cu(II) complexes with 2-carboxybenzaldehyde thiosemicarbazone. Spectrochim Acta A Mol Biomol Spectrosc 2014;129:333-8.

5. Dobrova A, Platzer S, Bacher F, Milunovic MN, Dobrov A, Spengler G, et al. Structure-antiproliferative activity studies on 1-proline- and homoproline-4-N-pyrrolidine-3-thiosemicarbazone hybrids and their nickel(ii), palladium(ii) and copper(ii) complexes. Dalton Trans 2016;45:13427-39.

6. Rogolino D, Cavazzoni A, Gatti A, Tegoni M, Pelosi G, Verdolino V, et al. Anti-proliferative effects of copper(II) complexes with hydroxyquinoline-thiosemicarbazone ligands. Eur J Med Chem 2017;128:140-53.

7. Zhu T, Shen S, Lu Q, Ye X, Ding W, Chen R, et al. Design and synthesis of novel N()-substituted thiosemicarbazones bearing a pyrrole unit as potential anticancer agents. Oncol Lett 2017;13:4493-500.

8. Yurttas L, Özkay Y, Kaplancıklı ZA, Tunalı Y, Karaca H. Synthesis and antimicrobial activity of some new hydrazone-bridged thiazole-pyrrole derivatives. J Enzyme Inhib Med Chem 2013;28:830-5. 
9. Anacona JR, Mago K, Camus J. Antibacterial activity of transition metal complexes with a tridentate NNO amoxicillin derived Schiff base. Synthesis and characterization. Appl Organomet Chem 2018;32:e4374.

10. Datar HE, Datar AJ. Antimicrobial activity of Anthoceplalus cadamba and Scirpus kysoor boxb. against food pathogens. Int J Curr Pharm Res 2016;8:13-8

11. Rajarajeswari C, Ganeshpandian M, Palaniandavar M, Riyasdeen A, Akbarsha MA. Mixed ligand copper(II) complexes of 1,10-phenanthroline with tridentate phenolate/pyridyl/(benz)imidazolyl Schiff base ligands: Covalent vs non-covalent DNA binding, DNA cleavage and cytotoxicity. J Inorg Biochem 2014;140:255-68.

12. Manimaran A, Jayabalakrishnan C. DNA-binding, catalytic oxidation, $\mathrm{CC}$ coupling reactions and antibacterial activities of binuclear $\mathrm{Ru}$ (II) thiosemicarbazone complexes: Synthesis and spectral characterization. Int J Adv Res 2012;3:233-43.

13. Pooja P, Meenakshi D, Amol K, Ganesh N, Smita P. Design, synthesis, docking studies and biological evaluation of 2-phenyl-3-(substituted benzo $[d]$ thiazol-2-ylamino)-quinazoline-4(3H)-one derivatives as antimicrobial agents. Int J Pharm Pharm Sci 2018;10:57-61.

14. Ilies DC, Pahontu E, Shova S, Georgescu R, Stanica N, Olar R, Gulea A, Rosu T. Synthesis, characterization, crystal structure and antimicrobial activity of copper (II) complexes with a thiosemicarbazone derived from 3-formyl-6-methylchromone. Polyhedron 2014;81:123-31.

15. Kumar MP, Tejaswi S, Rambabu A, Kalalbandi VK. Synthesis, crystal structure, DNA binding and cleavage studies of copper (II) complexes with isoxazole Schiff bases. Polyhedron 2015;102:111-20.

16. Aljahdali M, El-Sherif AA. Synthesis, characterization, molecular modeling and biological activity of mixed ligand complexes of $\mathrm{Cu}$ (II), Ni (II) and Co (II) based on 1, 10-phenanthroline and novel thiosemicarbazone. Inorganica Chim Acta 2013;407:58-68.

17. Afrasiabi Z, Sinn E, Kulkarni PP, Ambike V, Padhye S, Deobagakar D, et al. Synthesis and characterization of copper (II) complexes of 4-alkyl/ aryl-1, 2-naphthoquinones thiosemicarbazones derivatives as potent DNA cleaving agents. Inorganica Chim Acta 2005;358:2023-30.

18. El-Sawaf AK, El-Essawy F, Nassar AA, El-Samanody ES. Synthesis, spectral, thermal and antimicrobial studies on cobalt (II), nickel (II), copper (II), zinc (II) and palladium (II) complexes containing thiosemicarbazone ligand. J Mol Struct 2018;1157:381-94.

19. Shawish HB, Maah M, Halim SN, Shaker SA. Synthesis, characterization and structural studies of binuclear nickel (II) complexes derived from dihydroxybenzaldehyde thiosemicarbazones, bridged by 1, 2-bis (diphenylphosphino) ethane. Arabian J Chem 2016;9:S1935-42.

20. Shebl M, Ibrahim MA, Khalil SM, Stefan SL, Habib H. Binary and ternary copper(II) complexes of a tridentate ONS ligand derived from 2-aminochromone-3 carboxaldehyde and thiosemicarbazide: Synthesis, spectral studies and antimicrobial activity. Spectrochim Acta A Mol Biomol Spectrosc 2013;115:399-408.

21. Hathaway B, Billing DE. The electronic properties and stereochemistry of mono-nuclear complexes of the copper (II) ion. Coord Chem Rev 1970;5:143-207.

22. Loganathan R, Ramakrishnan S, Suresh E, Riyasdeen A, Akbarsha MA, Palaniandavar M. Mixed ligand copper (II) complexes of N, N-bis (benzimidazol-2-ylmethyl) amine (BBA) with diimine co-ligands: Efficient chemical nuclease and protease activities and cytotoxicity. $\mathrm{J}$ Inorg Chem 2012;51:5512-32.

23. Jeyalakshmi K, Arun Y, Bhuvanesh NS, Perumal PT, Sreekanth A, Karvembu R. DNA/protein binding, DNA cleavage, cytotoxicity, superoxide radical scavenging and molecular docking studies of copper (ii) complexes containing $\mathrm{N}$-benzyl-N'-aryl-N"-benzoylguanidine ligands. Inorg Chem Front 2015;2:780-98.

24. Joseph M, Kuriakose M, Kurup MP, Suresh E, Kishore A, Bhat SG. Structural, antimicrobial and spectral studies of copper (II) complexes of 2-benzoylpyridine N (4)-phenyl thiosemicarbazone. Polyhedron 2006;25:61-70.

25. Ramakrishnan S, Shakthipriya D, Suresh E, Periasamy VS, Akbarsha MA, Palaniandavar M. Ternary dinuclear copper (II) complexes of a hydroxybenzamide ligand with diimine coligands: The 5, 6-dmp ligand enhances DNA binding and cleavage and induces apoptosis. J Inorg Chem 2011;50:6458-71.

26. Javarappa R, Nagaraja N. Synthesis and screening of benzofuran fused $C-2,4,6$-substituted pyrimidine derivatives as a new antibacterial and antifungal agent. Int J Pharm Pharm Sci 2017;9:27-32.

27. Wang Q, Mao H, Wang W, Zhu H, Dai L, Chen Y, et al. Synthesis, X-ray crystal structure, DNA/BSA binding, DNA cleavage and cytotoxicity studies of phenanthroline based copper (II)/zinc (II) complexes. Biometals 2017;30:575-87.

28. Ganeshpandian M, Ramakrishnan S, Palaniandavar M, Suresh E, Riyasdeen A, Akbarsha MA. Mixed ligand copper (II) complexes of 2, 9-dimethyl-1, 10-phenanthroline: Tridentate $3 \mathrm{~N}$ primary ligands determine DNA binding and cleavage and cytotoxicity. J Inorg Biochem 2014;140:202-12. 